\title{
Ireland, Rent, and the Theologies of Real Estate
}

\author{
Kevin Hargaden
}

In this paper, taking the Irish economic crash of 2008 as the starting point, a theological response to real estate speculation is considered. By analysing the ways in which property development was a key factor in the collapse of the Irish economy, the flaws of such markets in crisis are exposed. Yet ethical concerns persist even when real estate markets are stable. Drawing on the Christian tradition around usury, an argument is made that an appropriate ecclesial reaction to the problems created by economies largely driven by real estate speculation involves developing alternative modes of conceiving land and economy. By drawing on the Vineyard song of Isaiah 5, a claim is made that faithful Christian practice demands a response of economic experimentation around property driven by a telos other than profit.

\section{The Celtic Tiger and Rent}

\begin{abstract}
There are forty-four houses in this estate. I live in number twenty-three. There's an old lady living in number forty. There's no one living in any of the other houses, just the ghosts of people who never existed. I'm stranded, she's abandoned. She never has visitors. I should go down to her, really. When Daddy and me went in to the auctioneers to ask about these houses, they let on they were nearly all sold. I wanted a corner house with a bigger garden, but the guy started fake-laughing, as if I was after asking for a solid gold toilet or something. He had at least half a jar of gel in his hair. I'll see what I can do, he said to my chest, in a martyred voice. He shook his head and sighed and said we'd have to pay the deposit that day. He said he couldn't promise us any of the houses would still be available the next day. I believed him, even though I should have known better. Daddy got all worried and flustered then, and drove like a madman back to the Credit Union to get me the cash. I'd love to go in to that auctioneer now and kick him in the balls. ${ }^{1}$
\end{abstract}

These are the opening lines from the character Réaltín, in Donal Ryan's novel The Spinning Heart; one of the few prominent creative works to engage directly with the aftermath of the Irish economic crash of 2008. In the novel Ryan uses the perspective of a range of residents in a rural Tipperary village to describe the private, domestic heartbreak that follows from a deep economic depression. Réaltín's experience is shared by hundreds of thousands of people across Ireland, whose entry into the property market has now left them in negative equity and in many cases, with mortgages that cannot be

${ }^{1}$ Donal Ryan, The Spinning Heart (Dublin: Doubleday Ireland, 2012), p. 42. 
paid. Although there are indicators of economic recovery, the period of austerity since 2008 has left lasting damage to Irish society.

In this essay, we will examine the Irish economy through the question of real estate and consider what theological resources are available to more accurately describe what happened in 2008 as well as what can be done now. The argument is that dysfunctional rental markets are effectively usurious. The response, informed by a reflection on the vineyard song of Isaiah 5, is to engage in practices within the economic sphere that demonstrate the allegiance of Irish Christians to that vineyard owner, over and against the prevailing economic orthodoxies.

The crash of 2008 brought an end to a period of sustained Irish economic growth that came to be known as 'the Celtic Tiger'. This period, representing a 'Golden Age of modern Irish economic history', ${ }^{2}$ was marked by GDP growth, GNP growth, increasing employment, reducing public debt ratios and a raft of other signifiers of economic health. ${ }^{3} \mathrm{~A}$ speculative property boom was at the heart of the expansion, and at the heart of that property boom was a concerted tax policy. From 1981, but supplemented extensively in 1987, the Dublin government pushed a property stimulus called Section 23. The provision, which applied to designated areas set aside for redevelopment, was remarkably generous. Tax relief was provided to the amount of the price of the property, excluding the cost of the site. The claimant could stretch the relief out over ten years. In effect, investors could secure tax-free rental income on any property they bought, in practically any urban area of Ireland, whether commercial, industrial or residential, for a decade. Furthermore, any excess relief could then be extended to other property either previously owned or later purchased. It was promoted as a temporary measure to encourage a struggling construction industry but it effectively reduced tax liability in proportion to investment in property development. In various incarnations, this policy persisted for well over two decades, only tapering off before the economic collapse of 2008.

On top of Section 23 allowances, Celtic Tiger era governments 'halved capital gains tax, reduced capital acquisitions tax, brought corporate taxes lower and introduced a series of income tax cuts. ${ }^{4}$ In 1998 and 1999 the 'taxes on profits from residential development and on development land were halved to 20 per cent.' ${ }^{5}$ Alongside these broad and, in some cases, universal measures, Ross lists some of the niche allowances created by the Celtic Tiger era governments. 'Capital allowances were on offer for hotels, holiday camps and holiday cottages, sports injury clinics, third-level education buildings, student accommodation, multi-storey car parks, park and ride facilities, crèches, private hospitals and nursing homes.' ${ }^{\prime}$ The effect of these fiscal instruments, alongside the tremendous increase in lending capital made available to Irish financial institutions as a result of membership of the Eurozone, ${ }^{7}$ was to tilt the entire national economy towards

2 Peter Clinch, Frank Convery and Brendan Walsh, After the Celtic Tiger (Dublin: O'Brien Press, 2002), p. 180.

3 Peadar Kirby, Celtic Tiger in Collapse (Basingstoke: Palgrave MacMillan, 2010), pp. 32-35.

4 Shane Ross, The Bankers (Dublin: Penguin, 2009), p. 123.

5 Ibid.

6 Ibid., p. 124.

7 At an conference organised by the International Monetary Fund at Dublin Castle in January 2015, to reflect on Ireland's recovery, Barry Eichengreen of Berkeley University argued that the relative 'ease of accessing wholesale funding given the perception that the exchange risk that would have 
property development and acquisition. By 2006, the construction industry represented 24 per cent of the gross national product. ${ }^{8}$

Without the global financial crisis, over the matter of property alone, Ireland's boom was almost certain to bust. Between 1985 and 2006, property prices in Finland and Italy rose by 50 per cent, in France by 75 per cent, in the UK by 140 per cent and in Ireland by almost 250 per cent. ${ }^{9}$ In the five years from 2004, new house completions in the Republic of Ireland averaged over 75,000 homes a year. ${ }^{10}$ To put this figure in perspective, that is just under half the completion rate over the same period in England, ${ }^{11}$ a country with over thirteen times the population, undergoing a property boom of its own.

Through the latter stages of the Celtic Tiger era it was occasionally discussed in the Irish media that the economy may be over-heating, in a large part due to property speculation. Yet the official message was that the fundamentals of the Irish economy were sound and that if the property market was to shrink, it would do so with a soft landing. ${ }^{12}$ Julien Mercille has demonstrated how representations of the construction sector and property market in the media played a crucial role in sustaining the property bubble. He records 'between 2000 and 2007, the Irish Times published more than 40,000

otherwise been associated with making local-currency loans to Irish banks was absent in a monetary union' invariably must be considered a cause of the crisis. (Barry Eichengreen, 'The Irish Crisis and the EU from a Distance', conference paper, Ireland - Lessons from Its Recover from the BankSovereign Loop (Dublin: IMF, 2015), p. 2), available online at http://www.imf.org/external/ $\mathrm{np} /$ seminars/eng/2014/ireland/ (accessed 2015-12-11).

8 Ross, p. 124.

9 Fintan O'Toole, Ship of Fools (London: Faber and Faber, 2009), p. 101.

10 The exact figure is 76,216. (Department of the Environment, Heritage and Local Government, Annual Housing Statistics Bulletin 2008 (Dublin: Department of the Environment, Heritage and Local Government, 2008), p. 43),

available online at http://www.environ.ie/en/Publications/StatisticsandRegularPublications /HousingStatistics/FileDownLoad,20957,en.pdf (accessed 2015-04-27).

11 During this period, on average England saw 159,714 new builds annually. Therefore, in the late period of the Irish property bubble, Ireland was building $47.7 \%$ of the houses that England was producing, even though Irish population is just over 7\% of England's. (Department for Communities and Local Government, 'Table 209', Live tables on house building, available online at https://www.gov.uk/government/statistical-data-sets/live-tables-on-house-building (accessed 2015-04-27).

12 The prominent economist and journalist Marc Coleman wrote that ' $\mathrm{f}]$ ar from an economic storm - or a property shock - Ireland's economy is set to rock and roll into the century.' (Marc Coleman, 'We Need these Expert Scaremongers', Sunday Independent, 23 September (2007), available online at http://www.independent.ie/opinion/analysis/we-need-these-expertscaremongers-26320180. html (accessed 2015-04-27).) The columnist and television presenter Brendan O'Connor wrote in the summer of 2007 that 'the smart, ballsy guys are buying up property right now'. (Brendan O'Connor, 'The Smart, Ballsy Guys Are Buying up Property Right Now', Sunday Independent, 29 July (2007), available online at http://www.independent.ie/opinion/analysis/the-smart-ballsyguys-are-buying-up-property-right-now-26307728.html (accessed 2015-04-27)). As Julien Mercille has demonstrated, these populist figures were joined by acknowledged experts from the industry and the academy, reassuring people that the fundamentals of the market were strong (The Political Economy and Media Coverage of the European Economic Crisis: The Case of Ireland (Abingdon: Routledge, 2014), pp. 38-44. 
articles about the economy, but only 78 were about the property bubble, or 0.2 per cent. ${ }^{\prime} 13$ The belief in property speculation as a means for profit was sustained by authoritative voices speaking in concert. A dogmatic orthodoxy was at play.

When the crash came, beginning in late 2007 but accelerating apocalyptically in September 2008, the Irish economy was devastated. Independent of the global financial collapse, the Irish property market had halted. As Michael Lewis summarises it: 'since 2000, Irish exports had stalled and the economy had become consumed with building houses and offices and hotels.' ${ }^{14}$ The shocks reverberating from the Lehmann Brothers' collapse caused a liquidity crisis in the six Irish banks. Operating out of the rationale that this was only a temporary blimp caused by global factors and not an internal structural problem precipitated by the global tremors, the government's initial response was to issue a guarantee on all bank deposits and bank bonds. ${ }^{15}$ In the days and weeks that followed, regardless of government positioning, it became clear that this was not a temporary blip.

The jump in unemployment arising from the construction slowdown simultaneously prompted a decline in income tax revenue and an increase in social welfare payments. The fiscal devices that had encouraged construction through the boom now served to perversely exacerbate the state's precarious financial situation. The tax base had evolved to rely heavily on tax revenue derived from construction industry activity. ${ }^{16}$ The global credit crunch was not primarily causal in this breakdown, but acted as a catalyst, accelerating the effects of the underlying problems. All this meant that, as Karl Whelan puts it, 'real GDP declined by ten percent over 2008 and 2009 ... without fiscal adjustment, Ireland was heading for annual deficits of as large as 20 percent of GDP.'17 An IMF and EU bailout package was initiated in 2010 and in 2015, having endured seven successive years of austerity budgets, the Irish economy is still severely hampered by high levels of private indebtedness accrued primarily through the property bubble, and the public debt burden taken on in the aftermath of the bubble bursting.

The bubble inflated because of people's trust in the viability of an economy based around profit derived from rent. ${ }^{18}$ In the ordinary course of things, real estate speculation works by leveraging equity to secure a mortgage that allows asset accumulation in the form of property that can be rented out for profit. When this market

13 Mercille, The Political Economy, p. 38.

14 Michael Lewis, Boomerang (London: Penguin, 2011), p. 91.

15 Michael Lewis is very clear in describing just how curious a decision this was (Boomerang, pp. 114-116).

16 'Furthermore, Ireland's tax base had been altered during the later periods of the boom to collect more and more tax revenue from construction activity.' (Karl Whelan, 'Ireland's Economic Crisis: The Good, the Bad and the Ugly', UCD Centre for Economic Research Working Paper Series WP13/06, July (2013), p. 10, available online at http://www.ucd.ie/t4cms/WP13_06.pdf (accessed 2015-0427).

17 Ibid.

18 Rent defined as 'payment for use of a resource, whether it be land, labour, equipment, ideas or even money' in John Eatwell, Murray Milgate and Peter Newman (Eds.), The New Palgrave: A Dictionary of Economics Volume 4 Q-Z (London: Macmillan Reference, 1998), p. 141. In this paper we are dealing with this commonplace usage of the term and do not mean the more technical understanding of economic rent that is a measure of market power or the related concepts of quasirents and differential rents. 
is functioning, it can be an efficient way to distribute resources. Long before the crash, it had stopped functioning efficiently in Ireland.

There were prophets denouncing this false faith. In one famous 2003 broadcast, the Irish economist David McWilliams announced that 'The Irish housing market is a scam. It is an enormous financial swindle that could potentially confine an entire generation of young Irish workers to years of bad debt.'19 In response to a sceptical 2007 report from the economic historian Morgan Kelly,20 the Irish Prime Minister of the time, Bertie Ahern, railed that 'sitting on the side-lines or sitting on the fence, cribbing and moaning, is a lost opportunity. In fact, I don't know how people who engage in that don't commit suicide.' ${ }^{21}$ The dogmatic orthodoxy had its priests. The authorities were to be trusted.

In Ireland, the commitment to property development became uncritical. The property bubble meant that debt overwhelmed the system. That bubble was made possible because the market for property became the focus of the hopes of the society, a quasi-religious commitment to self-defeating actions. Ireland's recent economic history is an example of credit-based speculation on a fundamental of human life (property) which created a devastating cycle of debt. That cycle was made possible by unchecked, uncritical and unfounded faith in invisible hands administering material gain.

\section{The Problems of Rent}

Thus, the recent story of the Irish economy is that of an economy mired in debt, in pursuit of profit from rent. Adam Smith himself famously declared that 'landlords, like all other men, love to reap where they never sowed, and demand a rent even for the natural produce of the earth.' 22 He cited the leasing of rocks that were home to wild, naturally occurring kelp as a particular egregious example of local landlord theft in the Scotland of his day. ${ }^{23}$ These rocks yielded a harvest without human intervention and were often even below the high tide mark. Yet the political power of the landowner created a context where a rent could be extracted. Smith was analysing a stable property market, not one in crisis like Ireland in 2008. This indicates that even in a normally functioning property market, real estate trading involves ethical complications.

Real estate investment markets can serve to widen inequality. An integral assumption of the property speculation market is that long-term investment in land and

19 Radio Telifís Éireann, Prime Time, 16 October (2003), available online at https:/ / www.youtube.com/watch?v=6gWPmufcOTo (accessed 2015-04-27).

20 Morgan Kelly, 'On the Likely Extent of Falls in Irish House Prices', Quarterly Economic Commentary (Dublin: ESRI, Summer 2007), available online at http:/ / www.esri.ie/UserFiles/publications/20070628164646/QEC2007Sum_SA_Kelly.pdf (accessed 2015-04-27).

${ }^{21}$ Bertie Ahern, 'Remarks Made At Irish Congress of Trade Unions Conference', 4 July (2007), available online at https://www.youtube.com/watch?v=hfjGSfuSQpA (accessed 2015-04-27).

22 Adam Smith, An Inquiry Into the Nature and Causes of the Wealth of Nations, vol 1 (Indianopolis, IN: Liberty Fund, 1981), p. 65.

23 Ibid., 161. 
property will hedge against inflation. ${ }^{24}$ Thomas Piketty argues that 'for most people, the simplest way to invest is to buy a home' and that 'this provides protection against inflation,' 25 as well as a removal of monthly rental charges. The problem is that 'for a person with 10 to 50 thousand euros, it is not enough to decide to buy a home: the possibility may not exist.' It is even harder in major urban areas where those 'whose pay is not in the top 2 or 3 centiles of the wage hierarchy' will find it hard to secure a home 'even if one is willing to go into debt for a long period of time and pay a high rate of interest. ${ }^{\prime 26}$ Whereas for those in the population with ready access to large amounts of capital, they can easily find themselves 'in a position to buy a home or apartment and therefore earn a real return of $3-4$ percent on their investment while being able to save more thanks to not having to pay rent. ${ }^{27}$ Over the medium term and especially over generations, without intervention, this dynamic leads to the emergence of a capitalcontrolling class.

That the ability to invest in property is limited based on access to capital, and that this ability can be a chief opportunity to accumulate further capital, leads to the second complication. The material resources at the disposal of landlords make them an influential group within the political sphere. In the Irish instance, the close collaboration between property developers and politicians did not even take place behind closed doors, but was conducted out in the open, most notably in 'the legendary Fianna Fáil fundraising tent at the Galway races' where speculators paid up to $€ 4,000$ for a chance to dine with elected representatives from the ruling party. ${ }^{28}$ An example of political influence from private landlord consortiums in a stable property market is the British government spare room subsidy policy, colloquially known as the 'bedroom tax'. The intention of the policy is to reduce housing expenditure by the state through the utilisation of 'existing public sector housing stock' ${ }^{29}$ In effect, this involves an elimination of public housing spending to incentivize the development of more extensive landlord holdings.

The political influence that comes with the accumulation of capital creates a double negative effect on those who are excluded from wealth. Marx is helpful here in portraying how the political disenfranchisement of the worker is associated with the worker's ability to accumulate reserves. 'The capitalist can live longer without the worker than can the worker without the capitalist' and this is so in a large part because the 'landowner and the capitalist can make use of industrial advantages to augment their revenues' where the worker 'has neither rent nor interest on capital to supplement his

24 For representative examples across the decades: Eugene F. Fama and G. William Schwert, 'Asset Returns and Inflation', Journal of Financial Economics 5:2 (1977), pp. 115-146; David Hartzell, John S. Hekman, and Mike E. Miles, 'Real Estate Returns and Inflation', Real Estate Economics 15:1 (1987), pp. 617-637; Jack Rubens, Michael Bond, and James Webb, 'The Inflation-Hedging Effectiveness of Real Estate', Journal of Real Estate Research 4:2 (1989), pp. 45-55; and Dirk Brounen et al, 'Inflation Protection from Homeownership: Long-Run Evidence, 1814-2008', Real Estate Economics 42:3 (2014), pp. 662-689.

25 Thomas Piketty, Capital in the Twenty-First Century (Cambridge, MA: Belknap Press, 2014), p. 454.

26 Ibid.

27 Ibid.

28 Frank McDonald and Kathy Sheridan, The Builders (Dublin: Penguin, 2009), pp. 18-19.

29 House of Commons Scottish Affairs Committee, The Impact of the Bedroom Tax in Scotland: Devolving the DHP Cap (London: The Stationery Office, 2014), p. 5. 
income. ${ }^{30}$ The worker who needs to earn wages to provide housing is discouraged from industrial agitation by the imminent arrival of rent-day and is discouraged from political agitation by the inability to deploy industrial agitation as a technique. Thus, the initial inability to gather enough capital to purchase a house leaves the poor exposed to inflation, bound to rental fluctuation, and consequently less likely to gather enough in the future. When coupled with the corresponding opportunities afforded the landlord and the way that capital reserves can be extended into political influence, we begin to see that there are ethical considerations that must be acknowledged around even a functioning real estate market.

\section{Dysfunctional Rental Markets as a Form of Usury?}

The Christian tradition offers rich possibilities for considering real estate from different angles. ${ }^{31}$ In earlier centuries, Christians would have diagnosed the root of the distress suffered by Realtín in A Spinning Heart and the thousands of Irish citizens left unemployed and homeless after the 2008 crash as a problem of usury. Eric Kerridge has made the strong argument that 'there is all the difference in the world between usury and interest. ${ }^{\prime 2} \mathrm{He}$ defines interest as costs imposed on loans 'for the sole end of avoiding loss to the lender' ${ }^{33}$ Quoting an Elizabethan memorandum he summarises that 'Usury and trewe interest be thinges as contrary as falsehood is to truth'. ${ }^{34}$ That such a distinction can be maintained is strengthened by remembering that Christ himself seems to echo it, when hinging the Parable of the Talents around the collection of interest. ${ }^{35}$ Kerridge identifies four varieties of interest that emerged in early European market trading, but each is distinguished from usury by dint of being compensatory rather than profitable. ${ }^{36}$

The long Christian tradition of opposition to usury is sourced in the repeated prohibition of lending for profit in the Hebrew Scriptures. ${ }^{37}$ It is never fully revoked. Even an acknowledged reformer of the position - John Calvin - who grants that 'we need not conclude that all usury is forbidden,' remains clearly hostile to the general principle

\footnotetext{
30 Karl Marx, Economic \& Philosophic Manuscripts of 1844 (London: Lawrence \& Wishart, 1970), p. 65.

31 There are of course other ways to conceive of alternatives outside theology. Karl Polanyi's account of capitalism that embeds it as a contingent outcome of particular historical contexts would be one such alternative. Polanyi's account holds that capitalist markets are relatively recent innovations where labour, land and money are commodified in spite of the fact that 'according to the empirical definition of a commodity, they are not commodities.' Trading in land as if it can be possessed and owned, for Polanyi, is a category error. It is a fictional commodity. Such lines of inquiry are not explicitly pursued in this paper, but their congruence with the broader argument should be noted (Karl Polanyi, The Great Transformation (Boston, MA: Beacon Press, 2001), p. 75.

32 Eric Kerridge, Usury, Interest and the Reformation (Aldershot: Ashgate, 2002), p. 5.

33 Ibid., p. 6.

34 Ibid., p. 5.

35 Matthew 25:14-30; Luke 19:11-27.

36 Kerridge, p. 7.

37 As representative examples: Exodus 22:25-27; Deuteronomy 23:19-20; Leviticus 25:35-37; Ezekiel 18:13; Psalm 15:5.
} 
of lending money at interest, warning that usury 'almost always travels with two inseparable companions: tyrannical cruelty and the art of deception.' 38

David Graeber has noted that while 'usury, and by extension profit, was denounced' by Christian thinkers, rent was never explicitly challenged. ${ }^{39}$ Yet Graeber himself acknowledges that the tradition implicitly engages with the ethical question of rent in no less a figure than Martin Luther. In his 'Sermon on Usury,' Luther discusses the contemporary practice of Zinskauf. Zinskauf' was the purchase of a fixed annual income in exchange for a sum of capital, and was therefore claimed to be a sale rather than a loan and thus not usurious.' 40 Graeber summarises the financial technology as 'technically rent on leased property, which was basically a disguised form of interest-bearing loan.' ${ }^{41}$ Luther rejected such a proposal, concluding that 'whether this contract is usury or not, it accomplishes exactly the same thing'. ${ }^{42}$ Zinskauf was a primitive form of futures trading and is rejected by Luther, regardless of how innovative it is, because of how it privileges the wealthy over the impoverished. The creditor enters into the arrangement without risk; thus they make profit even when others are at a loss. Zinskauf reveals how usury and rent are often side-by-side.

It would be an odd claim to present functioning rental markets, whatever their complications, as usurious. Yet when we consider the sort of untrammelled lending that characterised the final years of the Celtic Tiger, this ancient Christian category may be found to apply. As a consequence of the Eurozone currency, Irish banks were able to draw down relatively unlimited lines of credit for domestic and commercial lending. Real estate speculation may have been the sharp edge of their loan portfolios but credit was extended throughout the market - mortgages and business loans, credit cards and cash lending. The tilting of the economy towards seeking profit from rent in real estate created a favourable environment for banks to lend with remarkable intensity. ${ }^{43}$ In all these loans, banks booked a profit on every single transaction, without any effective risk restraint, since the solution to a debtor getting into trouble was a re-doubling of their credit-line through loan consolidation. Charles R. Geisst captures this dynamic in the final chapter of his history of usury, Beggar Thy Neighbor. Discussing the practices that led to the 2008 financial crash, of which Ireland was just one small component, Geisst describes what the credit card industry called the 'default rate'. This 'was not the rate of cardholders who did not pay their bills but rather the interest rate applied to those who violated the card companies' collection policies in some manner.' Critically, for our argument, 'access to further credit was not denied, but a higher price was exacted for it.' ${ }^{44}$ Luther decried Zinskauf because of how it demanded profit without relationship and the sharing of

38 Mary Beaty and Benjamin W. Farley (trans.), Calvin's Ecclesiastical Advice (Edinburgh: T\&T Clark, 1991), p. 140.

39 David Graeber, Debt: The First 5,000 Years (Brooklyn, NY: Melville House, 2011), p. 439.

40 Sean Doherty, Theology and Economic Ethics: Martin Luther and Arthur Rich in Dialogue (Oxford: Oxford University Press, 2014), p. 55.

41 Graeber, p. 445.

42 Martin Luther, Luthers Works, Vol. 45 (Minneapolis, MN: Fortress, 1962), p. 297.

43 In 2004, Irish bank lending totalled $€ 256$ billion. By 2008, that had more than doubled to $€ 591$ billion. From 2004 to 2009, 'Irish people got into debt 15 times faster than the average European'. (David McWilliams, Follow the Money (Dublin: Gill \& Macmillan, 2009), pp. 35-36)

44 Charles R. Geisst, Beggar Thy Neighbor: A History of Usury and Debt (Philadelphia, PA: University of Pennsylvania Press, 2013), p. 329. 
burdens. An argument can be made that Christians today should decry the securitized lending system that inflates bubbles, distorts risks, and leaves the provision of human essentials such as places to live in the hands of largely unregulated markets.

When the crash came, the creditors were bailed out, the debtors were not. The Irish crash was marked by lending at profit without risk; in classical Christian terms it was usurious. The Christian tradition, in its suspicion of usury in general questions the methods underlying markets as we commonly construct them. How can theological ethics inform the task of responding to these concerns?

\section{Theology of Rental Collapse}

The Irish property bubble can be seen as a financial mania where society prioritised economic activity based around buying, selling and renting an essential of human life; that is homes for people to live in. The usurious credit-debt cycle initiated by consistent political determination to encourage real estate speculation permeated the economy so thoroughly that when the cycle ground to a halt, the rest of the economy shuddered to a stop as well.

While all bubbles may not be usurious, ${ }^{45}$ the Irish crash can be described in such terms. Large parts of the Christian tradition teach that usury, even sophisticated forms, is 'unjust in itself, for one part sells the other something non-existent, and this obviously sets up an inequality which is contrary to justice.' 46 In questioning the credit-based cornerstone of contemporary real estate speculation, Christian theology reminds us that the market economy has competition, so to speak, in its account of reality.

The Christian antagonism towards usury is sourced in the Scriptures. The accounts of the Old Testament prophets can provide a strong counter-vision for how to conceive of land, real estate, and rent, in ways that cast light on the current ethical dilemma of Ireland's housing crisis. The church has resources to draw from that are deeper than the Chicago School. Even if the context that contemporary Christians find themselves in is one where it is politically, socially, and economically infeasible to advocate the wholesale rejection of usury, such a line of argument can be reinvigorated by finding marginal spaces to enact practical experimentation with alternative conceptions of real estate.

The vision found in the Hebrew Scriptures for the nation of Israel is one in which land, and indeed economy, are to be understood as components of a larger social reality which is ordered towards a telos greater than profit. As Christians in Ireland seek to engage the economic collapse and the real suffering endured in its aftermath, this counter-vision found in the Scriptures can re-orientate action in constructive yet unexpected directions. At the beginning of the book of Isaiah we find a passage that illuminates the fundamental disjunction between Israel's attitude towards land and economy and that which we can take for granted today. It is an especially fruitful text to consider because of the way in which it casts light on the divine scrutiny extended to economic treatments of land that do not honour justice. The reading to be offered here is

45 The broader question of whether the bust that invariably follows the boom in modern capitalism can always be described as usurious is one that merits further reflection.

46 Thomas Aquinas, Summa Theologica, Vol. 38 (London: Blackfriars, 1975), p. 235 (II-II-78). 
an analogical one, seeking to re-consider the social context of our day having had our vision re-calibrated by the social vision found within this text. Isaiah 5 is a message of judgement against Jerusalem in the face of invasion and exile. The reading offered here does not seek to over-ride that primary interpretation, nor claim equivalency. Rather, it is an attempt to take a second look at the world we live in to see again how faithfulness to the story of the Lord of Hosts might prompt us to act differently in Ireland in 2015.

In Isaiah 5 we find the prophet recounting a love-song between $\mathrm{YHWH}$ and his people. The first verses recapitulate the call of Israel into the Promised Land, here imagined as a vineyard on a 'very fertile hill' (1). The land that flows with milk and honey is recast as a field cleared of stones, planted with choice vines, equipped with watchtowers and wine vats, ready to yield a harvest. This has not come to pass. Instead, 'it yielded wild grapes' (2).

The remaining five verses of the song move through a reflective interlude (verses 3-4) to words of harsh judgement (verses 5-7). The owner twice speaks of how having constructed such a vineyard, he expected a yield $(2,4)$ but in these last verses, with his expectation disappointed, he turns to 'a new series of verbs, that undo the constructive effect'. ${ }^{\prime 7}$ He will remove the hedge, it will be devoured. He will break down the walls. They will be trampled down (5). He will make it a waste. It will go unpruned and unhoed. It will be overgrown and famished of rain (6).

In the final verse, 7 , the prophet makes it clear to his hearers what is occurring in this song. The vineyard has been established by the Lord of Hosts. The vineyard is the house of Israel. The vine that has been planted is the people of Judah. The expected yield was justice. But instead of righteousness the Lord's investment produced bloodshed. In response to the cries he hears, judgement is his only possible recourse. The resources that Israel encounters are to serve their vocation, such that the land and the community are woven together, across space and persisting in time as a witness to the Lord. This has not come to pass.

Careful attention to passages such as this gives contemporary Christians an alternative way to consider the world in which they find themselves. There is much at work in this love-song.48 Fundamentally, Israel is being retold its own story as a nation of slaves set free from slavery by the action of YHWH. The prophet deploys the language of trading and the market, investing in real estate and developing property, recasting the covenantal relationship in a new register. Israel is YHWH's investment. The profit which he anticipates is the profit of justice and righteousness. The land into which he has led Israel cannot be taken as a personal inheritance to be usuriously traded, and used only for the sake of Israel. It is God's land, to be used for God's justice-purposes. When the entire identity of the people of Judah is described in terms of this economics of righteousness, the economic activity of the nation cannot be orientated towards rational self-interest.

\footnotetext{
47 Walter Bruggemann, Isaiah 1-39 (Westminster Bible Companion) (Louisville, KY: Westminster John Knox Press, 1998), p. 47.

48 John Chrysostom in his homily on this passage notes the complexity of the song. 'I sing for him, he says, and he and his deeds will be the subject of the song. If at the moment of accusing him he calls him beloved or well beloved, do not be surprised.' (Johanna Manley (Ed.), Isaiah Through the Ages (Menlo Park, CA: Monastery Books, 1995), p. 66)
} 
The Christians of Ireland, standing as heirs to this tradition, can find rebuke of their own activity in this passage. In verse 8 we read the prophet lament, 'Ah, you who join house to house, who add field to field, until there is room for no one but you, and you are left to live alone in the midst of the land!' As the church in Ireland stands among 992 ghost estates ${ }^{49}$ (unfinished housing developments) across its small country, they hear these words for themselves and see them with their own eyes. ${ }^{50}$ On the edges of every town and city, many rural villages and even out in the wilderness, the half completed carcasses of homes and office blocks stand empty as the Irish church reads the prophet's continued warning: 'The Lord of Hosts has sworn in my hearing: Surely many houses shall be desolate, large and beautiful houses, without inhabitant' (9). With severe poverty rising, homelessness growing and unemployment seemingly intractable, through the prophet the church glimpses a new way to consider society's plight: 'For ten acres of vineyard shall yield but one bath, and a homer of seed shall yield a mere ephah' (10). We begin to see in this text how recession might be the consequence of unjust and unrighteous self-accumulation. Economies can stagnate when the oppression of miś pāh

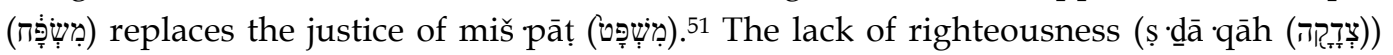

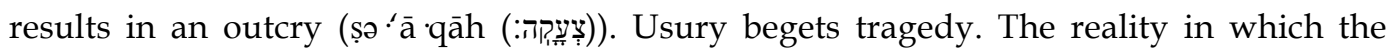
church is called to live does not exist in a tension between supply and demand but in a relationship between justice and righteousness.

By listening in on the cry of Isaiah and recognising that cry as one that obligates us, Christians in Ireland can go beyond a standard utilitarian calculus when considering their housing crisis and instead imagine a way of living in, occupying and investing in the space we call home without getting sucked into the vortex of debt-and-profit that has wreaked such havoc. The church has no fully-fledged alternative to capitalism ready to present. But the church is called to find ways to embody justice in this capitalist world. Where then, do these intimations lead us?

\section{A Call for Experimentation}

Ireland has seen seven years of austerity in the aftermath of the bursting of the property bubble. The long term consequences are only beginning to be understood. Serious material deprivation is on the rise. ${ }^{22}$ Food banks have newfound relevance in Irish cities. ${ }^{53}$

49 Housing Agency Ireland, Resolving Unfinished Housing Developments, Annual Progress Report 2014 (Dublin: Department of Environment, Community and Local Government, 2014), p. 4.

50 Valérie Anex, Ghost Estates (Geneva: Uqbar, 2013).

51 Jonathan Bonk describes the logic of this judgement, 'mesmerized by wealth and possessions, the priorities and orientations of the rich are often fatally misguided.' (Jonathan Bonk, Missions and Money (Maryknoll, NY: Orbis, 2008), p. 118)

52 Any number of metrics could be used to demonstrate this. One of the most recent is Eurostat's 'Severe Material Deprivation Rate' which shows Ireland's rate more than doubled between 2007 (4.5) and 2013 (9.9). (Eurostat, 'Severe material deprivation rate by tenure status', available online at http://appsso.eurostat.ec.europa.eu/nui/show.do?dataset=ilc_mddd17\&lang=en (accessed 201504-29).

53 '10 per cent of the Irish population was in food poverty' in 2010. (Caroline Carney and Bertrand Maître, Constructing a Food Poverty Indicator for Ireland (Dublin: Department of Social Protection, 2012), p. 41) 
A rental crisis is occurring as rental prices rise beyond the reach of the working poor ${ }^{54}$ and rental policies discriminate against those on welfare. ${ }^{55}$ As an outcome of this, homelessness is rapidly growing. ${ }^{56}$ How to handle what has been termed a 'housing crisis' is a topic commonly debated in parliament. ${ }^{57}$

In this context, when the church listens again to the Scriptures' view of land, market and economy, we find precious goods other than profit. When functioning, rental markets pose problems by encouraging the emergence of a capital controlling class and by increasing the political influence of landlords. The ethical task facing the church in such a setting may be to act in such a way as to oppose the unbalanced distribution of wealth and to politically enfranchise the excluded. In the first instance, the simple act of preaching must be considered. The pulpit-told truth that accurately describes injustice can open the eyes of those gathered to hear. In the second instance, inclusion in the political body that is the church is a means by which those who are muted in the public square are recognised and find a voice.

Yet this argument does not concern times when rental markets are functioning and people have houses to live in. In a context where the pursuit of profit through property speculation approaches or fully becomes a system of debt and usury, how can the church respond? Since the Reformation, Christians have grown increasingly comfortable with lending at interest but its indiscriminate deployment, which includes usurious deployment, is hard to square with the Scriptural testimony. Calvin, for example, offered six explicit exclusion zones and felt obliged to 'reiterate' that while it is tolerable in certain settings, he disapproved 'of anyone engaging in usury as his form of occupation'.58 Markets like the ones that surround real estate tend to be usurious by default and so risk becoming overwhelming bubbles that tilt entire societies into deficit. They turn a fictional commodity into the basis of shared reality, running the risk of idolatry. ${ }^{59}$ This is what has happened in Ireland. Bubbles, whether based around trading tulips, establishing internet businesses or selling apartments in rural Ireland, are always driven by belief. An unchecked faith and trust in the profitability of an endeavour prompts the market to lose touch with reality.

54 Órla Ryan, 'Rent in Dublin is up by $16.6 \%$, but what about other areas?', The Journal, 17 November (2014), available online at http://www.thejournal.ie/rent-increases-1783882-Nov2014/ (accessed 2014-04-29).

55 'The rent allowance payable by the Department of Social Protection has fallen by almost 30\% since 2011.' (Julian Mercille, 'Ireland Under Austerity', Counterpunch, 3 April (2014), available online at http:/ / www.counterpunch.org/2014/04/03/ireland-under-austerity-2 (accessed 2015-0429).

56 Kitty Holland, 'Number of homeless families in Dublin up 40\% since June', The Irish Times, 12 March (2015), available online at http://www.irishtimes.com/news/social-affairs/number-ofhomeless-families-in-dublin-up-40-since-june-1.2135724 (last accessed 29 April 2014).

57 Private Members Business, 'Dáil Éireann - Private Members Business (Sinn Féin) 23 - 24 September 2014', Parliamentary Report (Dublin: Tithe an Oireachtais, 2014), available online at http:/ / www.oireachtas.ie/viewdoc.asp?fn=/documents/ThisWeek/PMB-DAIL-2014/document 26.htm (accessed 2015-12-13).

58 Beaty and Farley, p. 142.

59 The slavery that comes from making an idol out of the land is perhaps most famously captured in Irish culture by the murder of the property developer William Dee by the anti-hero, Thady 'Bull' McCabe in John B. Keane's play The Field (John B. Keane, The Field (Cork: The Mercier Press, 1991)). 
The church is called to place its faith and trust in an entirely different set of priorities. As the church in Ireland seeks to witness to the Gospel in the context of economic devastation, a material embodiment of that faith surely involves putting its beliefs into practice in the economic sphere. This can begin with divestment from investments in industries that support reckless real estate development. ${ }^{60}$ When land and housing has been mis-directed as a tool for profit, the church might be called to go further, leveraging its own equity in disruptive property speculation. When people on social welfare can't find housing, the churches could acquire housing to house people. When over 111,000 mortgages are in arrears, ${ }^{61}$ the church can enter into the marketplace with the intention of acting in a way that does not heed the purchase that rent claims on our ethical action. The Lord of Hosts does not see profit in terms of financial gain but in terms of justice and righteousness, so perhaps the church can reveal what it believes by acquiring a property portfolio only with the intention of divesting of it into the hands of the homeless and the poor, the oppressed and the marginalised.

There are exciting examples of churches reacting to the aftermath of the 2008 crash on an institutional level. One thinks here of how the Church of England has sought to initiate grassroots transformation with a range of new economic endeavours. In league with the other churches in Britain they have launched the Churches' Mutual Credit Union to help church members save, developed the 'To Your Credit' programme that seeks to cultivate approaches to finance that are orientated towards the community good, produced curricula for primary school education about handling money and encouraged the development of community development finance institutions that will aim to go into market competition as alternatives to the predatory practices of payday creditors.

Individual congregations or individual congregational members can react to the particularities of their local setting in unique ways. The Cambridge-based economist Paul Mills has advanced an investment approach that, informed by the Christian traditions, seeks 'the absence of the exploitation of customers, workers, creditors and suppliers.' ${ }^{62}$ On this account, Christians should not seek to maximise their financial return but prioritize stewardship, the building of relationships, and realistic preparation for the future. Were this approach taken, a comfortably prosperous person would find themselves with liquidity that could be deployed in creative ways. Thus, a congregation may well find that they have the means amongst them such that young couples would

60 'Given the moral seriousness with which usury is treated in the Jewish and Christian traditions, investors have a responsibility to take every effort to assure themselves that the objects of their investment are not involved in usurious and predatory lending.' (David Clough, Richard Higginson and Michael Parsons, 'Usury, Investment and the Sub-Prime Sector', Association of Christian Economists Discussion Papers 001-003 (2009), pp. 1-23)

61 Banc Ceannais na hÉireann, Residential Mortgage Arrears and Repossessions Statistics: Q4 2014 (Dublin: Banc Ceannais na hÉireann, 2014).

62 Paul Mills, 'Investing as a Christian: Reaping where you have not sown?' Cambridge Papers 5, no. 2 (1996), p. 2. Interestingly, Mills suggests that Exodus 22:14-15 and Leviticus 25:14-16, 29-31 give 'tacit sanction to the renting or leasing of property for a return' (2) while questioning the broader debt-infused economic system. He discourages investment in bank deposits, building society deposits and even government debt since they serve 'little productive purpose' (3). In the light of the argument presented in this paper, Mills' nuanced position is noteworthy, whereby he can parse the validity of renting property while standing sceptically in relation to economies built on mortgage and rent. 
not need to take interest-bearing mortgages from financial institutions to buy homes for their families; a collective of older and financially established congregation members could pool the resources to buy the house and then gradually lease ownership to the young family on terms that were manageable. The benefit accrued here stretches beyond the bonds of community that grow strong when fellowship takes on such practical forms. Such experiments, which take place inside the market without assuming the markets axioms, have ramifications. They can serve to cool heated markets, slow the formation of bubbles and present alternatives to the usurious credit cycles.

On that same local level, Christians can seek to respond to the nexus of material deprivation that surrounds them by committing to new forms of intentional community that transgress the expected norms, drawing on the Christian practice of hospitality to transcend boundaries such as class, education, and religious background. The American minister and social activist, John M. Perkins, may provide a lead for how to begin exploring this option. Over the course of his long ministry, Perkins has overseen the rise of what is known as the 'Christian Community Development Association,' an alliance of churches that seek to work in deprived urban settings. One aspect of their methodology involves radical hospitality. Churches that are part of this group often encourage congregation members to open their homes to others or even to actively purchase new homes to live in communally. He gives the example of a church in the inner city of Jackson, Mississippi where three families

... covenanted together in 1986 to share their lives by buying a house and living in it together, welcoming others who are seeking spiritual development to live with them. Usually every room of their ten-bedroom, six-bath house is filled with people seeking direction, including single mothers, ex-offenders, and numerous teenagers. ${ }^{63}$

Approaches forged in the particular context of American urban poverty would require contextualisation for an Irish setting, but some version of the Christian Community Development Association model might prove to be very fruitful. Such a commitment to being communities of welcome would appear extreme by many standards, but such moves share a harmony with the vision of the vineyard in Isaiah 5 that the hermetically sealed safety of the nuclear family could never achieve. In a time of rising homelessness, such identification with those who need shelter - literally committing to live with them may be one potent practice to help the church discern a theology of real estate in an age of usurious booms and busts.

Experiments test hypotheses. The proposals listed here range from the eminently prudential to the expensively risky. They together constitute examples of how to test a hypothesis that emerges from historic Christian reflection on debt, usury and land: that we cannot be enriched if it involves the impoverishing of our neighbours. Theology cannot provide an alternative economic system for the world to embrace, but the church can embrace alternative economic experiments as an expression of its theology. Contemporary economic discourse speaks often in terms of 'innovation'. The property crash is an event in which the church has the opportunity to subversively embody the language of innovation and disruption, drawing on ancient wisdom and inhabiting it

63 John M. Perkins, Beyond Charity: The Call to Christian Community Development (Kindle Edition) (Grand Rapids, MI: Baker Publishing, 1993), Kindle Locations 908-910. 
with the mischief of the Kingdom. ${ }^{64}$ After all, the beloved of the Lord of Hosts is called to yield a profit of justice and righteousness.

Kevin Hargaden, University of Aberdeen kevin.hargaden@abdn.ac.uk

\section{Bibliography}

Anex, Valérie. Ghost Estates. Geneva: Uqbar, 2013.

Aquinas, Thomas. Summa Theologica, Vol. 38. London: Blackfriars, 1975.

Banc Ceannais na hÉireann. Residential Mortgage Arrears and Repossessions Statistics: Q4 2014. Dublin: Banc Ceannais na hÉireann, 2014.

Bonk, Jonathan. Missions and Money. Maryknoll, NY: Orbis, 2008.

Brounen, Dirk, Piet M. A. Eichholtz, Stefan Straetmans and Marcel A. J. Theebe. 'Inflation Protection from Homeownership: Long-Run Evidence, 1814-2008', Real Estate Economics 42 (2014), pp. 662-689.

Bruggemann, Walter. Isaiah 1-39. Louisville, KY: Westminster John Knox Press, 1998.

Calvin, John. Calvin's Ecclesiastical Advice, translated by Mark Beaty and Benjamin W. Farley. Edinburgh: T\&T Clark, 1991.

Carney, Caroline and Bertrand Maître. Constructing a Food Poverty Indicator for Ireland. Dublin: Department of Social Protection, 2012.

Clinch, Convery, Frank Convery and Brendan Walsh. After the Celtic Tiger. Dublin: O'Brien Press, 2002.

Clough, Higginson and Michael Parsons. 'Usury, Investment and the Sub-Prime Sector', Association of Christian Economists Discussion Papers 001-003 (2009), pp. 1-23.

Coleman, Marc. 'We Need these Expert Scaremongers', Sunday Independent 23 September (2007).

Department of the Environment, Heritage and Local Government, Annual Housing Statistics Bulletin 2008. Dublin: Department of the Environment, Heritage and Local Government, 2008.

Doherty, Sean. Theology and Economic Ethics: Martin Luther and Arthur Rich in Dialogue. Oxford: Oxford University Press, 2014.

Eatwell, John, Murray Milgate and Peter Newman (Eds.). The New Palgrave: A Dictionary of Economics Volume 4 Q-Z. London: Macmillan Reference, 1998.

Eichengreen, Barry. 'The Irish Crisis and the EU from a Distance', conference paper, Ireland - Lessons from Its Recover from the Bank-Sovereign Loop, Dublin, 2015. Online at: http://www.imf.org/external/ np/seminars/eng/2014/ireland/ (accessed 2015-1211)

Fama, Eugene F. and G. William Schwert. 'Asset Returns and Inflation', Journal of Financial Economics 5 (1977), pp. 115-146.

${ }^{64}$ The church here would only be extending work that has begun elsewhere. For example, Strike Debt's Rolling Jubilee campaign which buys effectively worthless debt with the intention of abolishing it. As of March 25th they had purchased $\$ 701317$ worth of debt and thus liberated $\$ 31,982,455.76$ worth of loans (http://rollingjubilee.org/). 
Graeber, David. Debt: The First 5,000 Years. Brooklyn, NY: Melville House, 2011.

Hartzell, Hekman, and Mike E. Miles. 'Real Estate Returns and Inflation', Real Estate Economics 15 (1987), pp. 617-637.

Holland, Kitty. 'Number of Homeless Families in Dublin up 40\% since June', The Irish Times, 12 March (2015).

House of Commons Scottish Affairs Committee. The Impact of the Bedroom Tax in Scotland: Devolving the DHP Cap. London: The Stationery Office, 2014.

Housing Agency Ireland. Resolving Unfinished Housing Developments, Annual Progress Report 2014. Dublin: Department of Environment, Community and Local Government, 2014.

Keane, John B. The Field. Cork: The Mercier Press, 1991.

Kelly, Morgan. 'On the Likely Extent of Falls in Irish House Prices', Quarterly Economic Commentary 2 (2007), pp. 42-54.

Kerridge, Eric. Usury, Interest and the Reformation. Aldershot: Ashgate, 2002.

Kirby, Peadar. Celtic Tiger in Collapse. Basingstoke: Palgrave MacMillan, 2010.

Lewis, Michael. Boomerang. London: Penguin, 2011.

Luther, Martin. Luthers Works, Vol. 45. Minneapolis, MN: Fortress, 1962.

Manley, Johanna (Ed.). Isaiah Through the Ages. Menlo Park, CA: Monastery Books, 1995.

Marx, Karl. Economic \& Philosophic Manuscripts of 1844. London: Lawrence \& Wishart, 1970.

McDonald, Frank, and Kathy Sheridan. The Builders. Dublin: Penguin, 2009.

McWilliams, David. Follow the Money. Dublin: Gill \& Macmillan, 2009.

Mercille, Julien. The Political Economy and Media Coverage of the European Economic Crisis: The Case of Ireland. Abingdon: Routledge, 2014.

Mercille, Julian. 'Ireland Under Austerity', Counterpunch, April 3 (2014).

Mills, Paul. 'Investing as a Christian: Reaping Where You Have Not Sown?', Cambridge Papers 5:2 (1996), pp. 1-4.

O'Connor, Brendan. 'The Smart, Ballsy Guys Are Buying up Property Right Now', Sunday Independent, 29 July (2007).

O'Toole, Fintan. Ship of Fools. London: Faber and Faber, 2009.

Perkins, John M. Beyond Charity: The Call To Christian Community Development. Grand Rapids, MI: Baker, 1993.

Piketty, Thomas. Capital in the Twenty-First Century. Cambridge, MA: Belknap Press, 2014.

Polanyi, Karl. The Great Transformation. Boston, MA: Beacon Press, 2001.

Private Members Business. 'Dáil Éireann - Private Members Business (Sinn Féin), 23 - 24 September 2014'. Parliamentary Report. Dublin: Tithe an Oireachtais, 2014.

Ross, Shane. The Bankers. Dublin: Penguin, 2009.

Rubens, Bond, and James Webb. 'The Inflation-Hedging Effectiveness of Real Estate'. Journal of Real Estate Research 4 (1989), pp. 45-55.

Ryan, Donal. The Spinning Heart. Dublin: Doubleday Ireland, 2012.

Ryan, Órla. 'Rent in Dublin Is Up by 16.6\%, But What about Other Areas?', The Journal, 17 November (2014).

Smith, Adam. An Inquiry Into the Nature and Causes of the Wealth of Nations, Vol 1. Indianapolis, IN: Liberty Fund, 1981.

Whelan, Karl. 'Ireland's Economic Crisis: The Good, the Bad and the Ugly'. UCD Centre for Economic Research Working Paper Series, University College Dublin, Dublin, July (2013). 